\title{
PENGARUH STRATEGI GREEN TOURISM DIFFERENTIATION TERHADAP KEPUASAN DAN MINAT KUNJUNG ULANG WISATAWAN HUTAN MANGROVE DI KABUPATEN KEBUMEN
}

\author{
Marynta Putri Pratama ${ }^{(1)}$ \\ Sigit Wibawanto ${ }^{(2)}$ \\ Prodi S1 Manajemen ${ }^{(1),(2)}$ \\ STIE Putra Bangsa \\ maryntaputri@yahoo.com ${ }^{(1)}$ \\ sigitpb3@gmail.com ${ }^{(2)}$
}

\begin{abstract}
Differentiation of green tourism towards satisfaction and interest in tourists visiting mangroves in Kebumen District. In 2017 Kebumen Regency is developing the natural tourism sector, one of which is the tourism of mangrove forests which is designated as ecotourism. Based on the number of visitor reports, which is known to occur in a significant number of visitors. Some visitors are visitors who visit again. For this reason, it is necessary to examine the marketing strategy development model that is able to assess factors that can increase competitiveness and tourist visits, as a basis for developing natural tourism in other natural attractions. The research methods used are quantitative descriptive surveys. The population in this study is mangrove tourists who have visited more than twice in one year. The sampling technique in this study uses convenience sampling. The statistical test tool used is path analysis with the help of the SPSS version 22 program.
\end{abstract}

Keywords: Green Differentiation Tourism, Satisfaction, Revisiting Interests.

\section{PENDAHULUAN}

\section{Latar Belakang}

Pemanfaatan wisata di daerah berpengaruh terhadap petumbuhan ekonomi daerah. Hal ini dilihat dari bertambahnya jumlah wisatawan yang datang dari waktu ke waktu, umumnya mereka yang berwisata ke hutan mangrove Kebumen, sekedar berlibur atau berpetualang menikmati keindahan kekayaan alamnya yang sangat menarik. Kawasan hutan mangrove yang letaknya tak jauh dari Pantai Logending Kecamatan Ayah, berpotensi menjadi destinasi wisata baru di Kabupaten Kebumen. Pasalanya, ekosistem mangrove menjadi produk wisata yang menarik karena menyajikan fenomena alam yang beragam, mulai dari keanekaragaman jenis mangrove, jenis-jenis fauna yang terdapat dalam ekosistem tersebut seperti burung, mollusca (siput atau keong), ikan, jenis-jenis crustacea (kepiting) dan hewan-hewan lainnya.

Salah satu obyek wisata yang saat ini menjadi primadona adalah hutan mangrove. Di kawasan mangrove ini, para pengunjung bisa mendapatkan banyak ilmu pengetahuan tentang hutan mangrove dan fungsinya bagi lingkungan, proses terjadinya suksesi, dan berbagai pengetahuan lainnya terkait ekosistem mangrove. Wisata ke kawasan ini akan menambah pengetahuan dan pengalaman par pengunjung. Selain sebagai penjaga garis pantai, kini lokasi itu telah menjadi kawasan edukasi. Bahkan, pengunjung tidak hanya dapat menikmati keindahan panorama alam di sana. Mereka pun dapat turut serta menjaga dan melestarikan hutan mangrove, salah satunya dengan cara menanam bibit pohon mangrove.

Peneliti telah melakukan survei pendahuluan terhadap 300 pengunjung wisata mangrove Kebumen. Sebanyak 71,5\% pengunjung merupakan wisatawan yang sudah pernah berkunjung ke wsiata hutan mangrove. Hal ini menunjukan tingginya minat wisatawan berkunjung ulang ke hutang mangrove. Hal ini menujukkan bahwa minat kunjung ke hutan mangrove meningkat, penelitian ini akan menguji faktor - faktor yang berpengaruh terhadap minat kunjung ulang. Dian Permana (2013) menyatakan bahwa strategi diferensiasi 
menyediakan produk yang dianggap konsumen sebagai suatu yang unik dan mempunyai nilai lebih, penting untuk dilakukan. Destinasi wisata dalam konteks bisnis, menghasilkan dan menawarkan produk usahanya kepada calon wisatawan. Oleh karena itu, produk harus memiliki diferensiasi tertentu. Produknya harus memiliki daya beda dan daya tarik bagi calon wisatawan. Strategi diferensiasi dapat dilakukan pada produk, pelayanan, kompetensi SDM, saluran penjualan, maupun citra wisata yang dibentuk.

Green tourism destination merupakan bentuk dari pengembangan konsep ekowisata. Menurut Chafid Fandeli (2000:34) ekowisata pertama diperkenalkan oleh organisasi The Ecotourism Society pada tahun 1990 dan menjelaskan bahwa ekowisata adalah suatu bentuk perjalanan wisata ke area alami yang dilakukan dengan tujuan mengkonservasi lingkungan dan melestarikan kehidupan dan kesejahteraan penduduk setempat. Penerapan diferensiasi produk yang berbasis green tourism diharapkan juga dapat membuat perbedaan sehingga berdampak lanjut terhadap komunitas lokal yang terlibat langsung. Selain itu penerapan ini dapat meminimalisir perusakan terhadap alam.

\section{PEMBAHASAN}

\section{Minat Kunjung Ulang}

Menurut Shadily (1987: 2252) kata "minat" berasal dari bahasa Inggris interest = perhatian, yaitu kecenderungan bertingkah laku yang terarah terhadap kegiatan objek kegiatan atau pengalaman tertentu. Minat mempunyai hubungan dengan intensionalitas, yaitu keterarahan dan pengarahan sebagai tanda penting bagi semua gejala hidup. Kecenderungan ini berbeda dalam intensitasnya pada setiap individu. Cronin dan Taylor (1992) dalam jurnalnya mendefinisikan minat beli ulang sebagai perilaku pelanggan dimana pelanggan merespon secara positif terhadap kualitas pelayanan suatu perusahaan dan ahirnya memunculkan minat kunjung ulang pada perusahaan tersebut atau minat beli ulang produk tersebut. Kualitas produk disini mempunyai daya tarik produk yang baik, sehingga dapat menimbulkan kesan positif terhadap pelanggan yang mengkonsumsi produk tersebut, yang kemudian memunculkan minat untuk membelinya kembali dilain waktu. Pada penelitian ini teori minat beli ulang dapat digunakan sebagai referensi minat kunjung ulang museum, karena minat kunjung ulang museum sama dengan minat membeli ulang tiket masuk museum. Minat membeli merupakan dorongan konsumen untuk melakukan pembelian atau dorongan yang dimiliki oleh seseorang untuk melakukan pembelian ulang. Minat beli ulang merupakan dorongan konsumen untuk melakukan pembelian atau dorongan yang dimiliki seseorang untuk melakukan pembelian ulang. Minat beli ulang merupakan bagian dari perilaku pembelian dimana didalam konteks minat beli ulang tersebut terdapat konsep loyalitas (Solderlund and Vilgon, 1999). Selain itu, Fornell (1992) menyatakan bahwa konsumen atau pelanggan yang puas akan melakukan kunjungan ulang pada waktu yang akan datang dan memberitahukan kepada orang lain atas jasa yang dirasakannya.

Dalam konteks minat kunjung ulang, menurut Hasan (2015) seberapa penting tindaknya daya tarik sebuah destinasi parawisata sangat penting tergantung pada apa yang diinginkan wisataan saat mereka menghabiskan waktu di detinasi, serta kondisi geografi destinasi itu sendiri. Umumnya wisatawan akan menafsirkan daerah wisata secara raional dan emosional. Oleh karena itu untuk membuat wisatawan bersedia mengunjungi kembali destinasi yang sama di masa yang akan datang dan merekomendasikan kepada orang lain. Menurut Zhu Mingfang dan Zhang Hanyu (dalam sopyan : 2015) indikatornya meliputi:

1. Minat untuk Berkunjung ulang.

2. Memberikan rekomendasi kepada orang lainWisatawan yang berusaha memberitahukan pengalamannya terhadap orang lain yang baru dikenal tentang hal positif melalui word of mouth.

3. Reputasi baik dimata pengunjung

Pencitraan baik wisatawan terhadap sebuah destinasi wisata yang telah mereka 
kunjungi dengan berbagai faktor yang mempengaruhi keputusan wisatawan untuk berkunjung kembali.

\section{Strategi Green Tourism Differentiation}

\section{Differentiation Strategy}

Diferensiasi produk menurut Kotler (2008:328) tindakan merancang serangkaian perbedaan yang berarti untuk membedakan tawaran perusahaan dengan tawaran pesaing. Sedangkan menurut Mowen dan Miror (2007:55) diferensiasi adalah proses manipulasi bauran pemasaran untuk menempatkan sebuah merek sehingga para konsumen dapat merasakan perbedaan yang berarti antara merek tersebut dengan pesaing. Secara umum, terdapat dua bidang syarat yang harus dipenuhi dalam memanfaatkan strategi ini, yaitu bidang sumber daya dan bidang organisasi. dari sisi sumber daya perusahaan, dibutuhkan kekuatan dalam hal pemasaran, kreativitas, dan bakat perekayasaan produk, riset pasar, reputasi perusahaan, distribusi dan keterampilan kerja. sedangkan dari organisasi, perusahaan harus kuat dan mampu untuk melakukan koordinasi antar fungsi manajemen yang terkait. Perusahaan harus dapat mendiferensiasikan produknya agar dapat menghadapi persaingan yang semakin ketat diantara perusahaanperusahaan yang memproduksi barang sejenis. Strategi diferensiasi produk yang diterapkan oleh wisata hutan mangrove adalah green tourism destination yang merupakan suatu destinasi tujuan wisata yang berkelanjutan dan ramah lingkungan serta melakukan konservasi terhadap lingkungan.Variabel utama diferensiasi produk menurut Kotler dan Amstrong (2011:211) yang digunakan pada penelitian ini diseusaikan dengan green tourism destination adalah

1. Green features (keistimewaan) dimana objek wisata dapat ditawarkan merupakan objek wisata unggulan dan menunjukan karakteristik dari wisata hutan mangrove.
2. Green Performance (kinerja) merupakan pelayanan dan jenis wisata yang diberikan yang diberikan kepada wisatawan yang datang ke wisata hutan mangrove dapat memuaskan, serta

3. Green style and design (gaya dan desain) merupakan penampilan dan perasaan wisatawan pada objek wisata hutan mangrove, karena objek wisata hutan mangrove berbeda dengan pulau lainnya.

Green tourism destination merupakan bentuk dari pengembangan konsep ekowisata. Menurut Chafid Fandeli (2000:34) ekowisata pertama diperkenalkan oleh organisasi The Ecotourism Society pada tahun 1990 dan menjelaskan bahwa ekowisata adalah suatu bentuk perjalanan wisata ke area alami yang dilakukan dengan tujuan mengkonservasi lingkungan dan melestarikan kehidupan dan kesejahteraan penduduk setempat.

\section{Kepuasan Wisatawan}

Kepuasan adalah perasaan senang atau kecewa pada seseorang yang timbul karena membandingkan kinerja yang dipersepsikan terhadap ekspetasi mereka (Kotler dan Keller, 2008). Kepuasan pelanggan juga dapat diartikan sebagai respon pelanggan terhadap ketidaksesuaian antara tingkat kepentingan sebelumnya dan kinerja aktual yang dirasakan setelah melakukan pemakaian (Rangkuti, 2002). Menurut Haerul Isra Harun (2013), kepuasan pelanggan ditentukan oleh kualitas jasa yang dikehendaki sehingga jaminan kualitas menjadi prioritas utama dan dijadikan tolak ukur keunggulan daya saing perusahaan. Secara umum, kepuasan konsumen merupakan kesesuaian antara yang diinginkan dan diharapkan pelanggan dengan kenyataan yang diperoleh. Tjiptono dalam (Yuniar : 2015). Indikator- indikator kepuasan pelanggan meliputi:

a. Kepuasan general atau keseluruhan (overall satisfaction) merupakan kepuasan masing-masing atas produk 
atau layanan, kepuasan total atas produk dan layanan.

b. Konfirmasi harapan (confirmation of expectation) merupakam kesesuain atau tidak sesuaian antara harapan pelanggan dengan kinerja produk dan layanan.

c. Perbandingan situasi ideal (comparison to ideal) merupakan keunggulan lebih yang dimiliki dari pada yang lain.

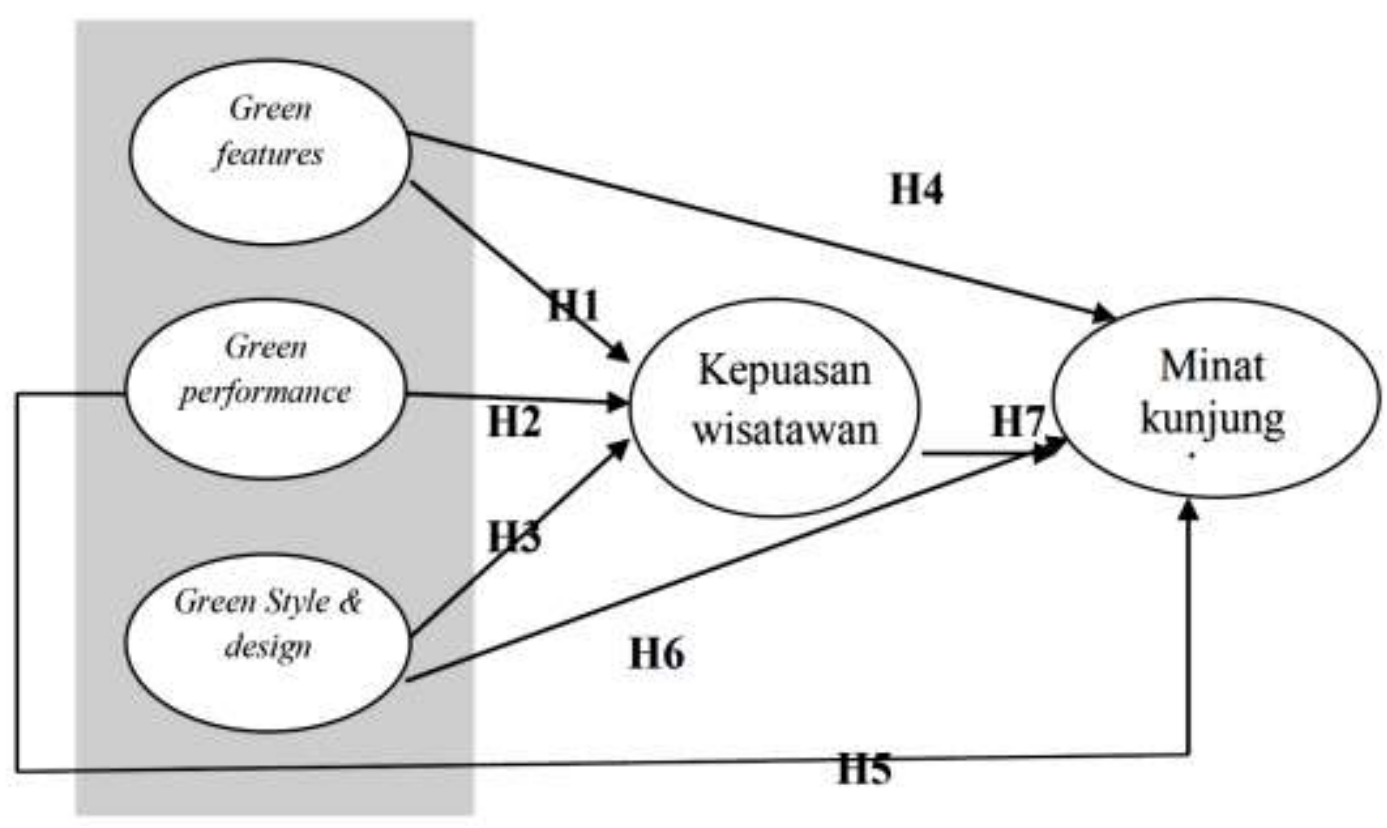

Gambar 1. Kerangka Pikir

\section{HIPOTESIS PENELITIAN}

Hipotesis merupakan pernyataan yang masih bersifat sementara yang harus dibuktikan kebenarannya untuk menjawab sebuah permasalahan. Hipotesis yang diajukan dalam penelitian ini antara lain:

H1: Green features berpengaruh terhadap kepuasan konsumen pada hutan wisatawan mangrove kebumen.

H2: Green Performance berpengaruh terhadap kepuasan konsumen pada wisatawan hutan mangrove kebumen.

H3: Green Style \& design berpengaruh terhadap kepuasan konsumen pada wisatawan hutan mangrove kebumen.

H4:Green Features berpengaruh terhadap minat kunjung ulang pada wisatawan hutan mangrove kebumen.

H5: Green performance berpengaruh terhadap minat kunjung ulang pada wisatawan hutan mangrove kebumen.
H6: Green Style \& design berpengaruh terhadap minat kunjung ulang pada wisatawan hutan mangrove kebumen.

H7: Kepuasan berpengaruh terhadap minat kunjung ulang pada wisatawan hutan mangrove kebumen.

\section{METODE PENELITIAN}

Lokasi dalam penelitian ini adalah kabupaten kebumen. Objek wisata hutan mangrove terletak Desa Lembu Purwo, Kecamatan Mirit, Kebumen. Populasi dalam penelitan ini adalah pengunjung hutan wisata mangrove kebumen yang telah berkunjung minimal dua kali dalam kurun waktu satu tahun. Teknik menentuan sampel dalam penelitian ini dengan menggunakan teknik convenience sampling sejumlah 100 responden. Metode convenience adalah teknik menentuan sampel berdasarkan kebetulan saja, anggota populasi yang ditemui peneliti dan bersedia menjadi responden akan dijadikan sampel (Suliyanto, 
2006). Karena di dalam penelitian ini jumlah populasi tidak diketahui, maka penentuan jumlah sampel dalam penelitian ini di ambil dengan menggunakan rumus sebagai berikut (Umar, 2000). Peneliti mengambil sampel sebanyak 100 orang agar dapat memenuhi syarat pengambilan sampel minimal.

Analisis jalur merupakan perluasan dari analisis regresi yang digunakan untuk menerangkan akibat langsung atau tidak langsung seperangkat variabel, sebagai variabel penyebab terhadap variabel lain yang merupakan variabel akibat.

Analisis jalur menghubungkan lebih dari dua variabel untuk mengetahui minat kunjung ulang (Y2) terhadap feature (X1), performance (X2), style \& design (X3), dan kepuasan (Y1), dapat digunakan rumus :

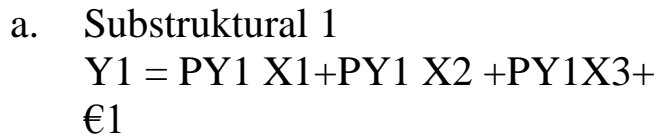

a. Substruktural 1$$
\mathrm{Y} 1 \text { = PY1 X1+PY1 X2 +PY1X3+ }
$$
$€ 1$

Tabel 1

Hasil Uji t Substruktural I

Coefficients $^{\mathbf{a}}$

\begin{tabular}{|c|c|c|c|c|c|c|}
\hline \multirow[b]{2}{*}{ Model } & & \multicolumn{2}{|c|}{$\begin{array}{l}\text { Unstandardized } \\
\text { Coefficients }\end{array}$} & \multirow{2}{*}{$\begin{array}{c}\text { Standardized } \\
\text { Coefficients } \\
\text { Beta }\end{array}$} & \multirow[t]{2}{*}{$\mathrm{T}$} & \multirow[t]{2}{*}{ Sig. } \\
\hline & & B & $\begin{array}{l}\text { Std } \\
\text { Error }\end{array}$ & & & \\
\hline 1 & (Constant) & 2.381 & 1.043 & & 2.283 & .025 \\
\hline & $\mathrm{x} 1$ & .177 & .039 & .393 & 4.515 & .000 \\
\hline & $\mathrm{x} 2$ & .194 & .070 & .264 & 2.760 & .007 \\
\hline & $\mathrm{x} 3$ & .101 & .063 & .151 & 1.604 & .112 \\
\hline
\end{tabular}

a. Dependent Variabel: y1

Tabel 2

\section{Hasil Uji t Substruktural II}

\section{Coefficients $^{\mathbf{a}}$}

\begin{tabular}{|c|c|c|c|c|c|c|}
\hline \multirow[b]{2}{*}{ Model } & & \multicolumn{2}{|c|}{$\begin{array}{c}\text { Unstandardized } \\
\text { Coefficients }\end{array}$} & \multirow{2}{*}{$\begin{array}{c}\text { Standardized } \\
\text { Coefficients } \\
\text { Beta } \\
\end{array}$} & \multirow[t]{2}{*}{$\mathrm{T}$} & \multirow[t]{2}{*}{ Sig. } \\
\hline & & B & $\begin{array}{l}\text { Std } \\
\text { Error }\end{array}$ & & & \\
\hline \multirow[t]{5}{*}{1} & (Constant) & 1.021 & 1.518 & & .672 & .503 \\
\hline & $\mathrm{x} 1$ & .183 & .061 & .318 & 2.984 & .004 \\
\hline & $\mathrm{x} 2$ & .050 & .103 & .053 & .481 & .631 \\
\hline & $\mathrm{x} 3$ & .236 & .091 & .275 & 2.596 & .011 \\
\hline & y1 & .024 & .145 & .019 & .167 & .867 \\
\hline
\end{tabular}

a. Dependent Variabel: y2

\section{HASIL PENELITIAN}

sebagai persamaan struktural 1

Dimana :

$\mathrm{Y} 1=$ Kepuasan, $\mathrm{X} 1=$ Green

Feature, X2= Green Performance,

$\mathrm{X} 3=$ Green Style \& Design, $€ 1=$

error

b. b. Substruktural 2

$\mathrm{Y} 2=\mathrm{PY} 2 \mathrm{X} 1+\mathrm{PY} 2 \mathrm{X} 2+\mathrm{PY} 2 \mathrm{Y} 1+€ 2$

sebagai persamaan struktural 2

Dimana :

$\mathrm{Y} 1=$ Kepuasan, $\mathrm{Y} 2=$ Minat

kunjung ulang, $\mathrm{X} 1=$ Green

Feature, X2 = Green Performance, X3 = Green Style \& Design, $€ 1=$ error

Uji t dilakukan untuk menguji signifikan
parsial pengaruh variabel bebas terhadap
bel intervening dan variable terikat dengan
at signifikansi $\alpha=0,05$.

Uji t dilakukan untuk menguji signifikan
secara parsial pengaruh variabel bebas terhadap
variabel intervening dan variable terikat dengan
tingkat signifikansi $\alpha=0,05$.

Uji t dilakukan untuk menguji signifikan
secara parsial pengaruh variabel bebas terhadap
variabel intervening dan variable terikat dengan
tingkat signifikansi $\alpha=0,05$.

Uji t dilakukan untuk menguji signifikan
secara parsial pengaruh variabel bebas terhadap
variabel intervening dan variable terikat dengan
tingkat signifikansi $\alpha=0,05$. 
Hasil pengujian di atas terbukti bahwa:

a. Green features berpengaruh positif terhadap kepuasan wisatawan (sig. 0,00). Hal ini menunjukkan bahwa semakin tinggi green features, maka semakin tinggi pula kepuasan. Hipotesis 1 diterima.

b. Green performance berpengaruh positif terhadap kepuasan wisatawan (sig. 0,007). Hal ini menunjukkan bahwa semakin tinggi green performance, maka semakin tinggi pula kepuasan. Hipotesis 2 diterima.

c. Green style and design tidak berpengaruh terhadap kepuasan wisatawan (sig. 0,112). Hal ini menunjukkan bahwa variasi atau perubahan green style and design tidak berpengaruh signifikan terhadap kepuasan waisatawan. Hipotesis 3 ditolak.

d. Green features berpengaruh positif terhadap minat kunjung ulang wisatawan (sig. 0,004). Hal ini menunjukkan bahwa semakin tinggi green features, maka semakin tinggi pula minta kunjung ulang. Hipotesis 4 diterima.

e. Green performance berpengaruh positif terhadap minat kunjung ulang wisatawan (sig. 0,631). Hal ini menunjukkan bahwa variasi atau perubahan Green performance tidak berpengaruh signifikan terhadap minat kunjung ulang wisatawan. Hipotesis 5 ditolak.

f. Green style and design tidak berpengaruh terhadap minat kunjung ulang wisatawan (sig. 0,112). Hal ini menunjukkan bahwa variasi atau perubahan green style and design tidak berpengaruh signifikan terhadap minat kunjung ulang waisatawan. Hipotesis 6 ditolak.

g. Kepuasan wisatawan tidak berpengaruh terhadap minat kunjung ulang wisatawan (sig. 0,867) . Hal ini menunjukkan bahwa variasi atau perubahan kepuasan wisatawan tidak berpengaruh signifikan terhadap minat kunjung ulang waisatawan. Hipotesis 7 ditolak.

\section{PEMBAHASAN}

Hasil analisis menunjukkan bahwa strategi green feature dan green performance berpengaruh terhadap kepuasan wisatawan. Wisata mangrove memanfaatkan konservasi hutan mangrove sebagai wahana wisata yang menarik wisatawan. Keberagaman flora dan fauna di hutan mangrove menjadi daya tarik tersendiri bagi wisatawan. Selain itu wisata hutan 28 mangrove juga dilengkapi perahu kecil yang bisa disewa wisatawan untuk berkeliling hutan mangrove. Wisata ini juga menyediakan pemandu lokal yang mampu menceritakan latar belakang pengembangan wisata hutan mangrove. Hasil penelitian ini sesuai dengan penelitian Ababneh (2013). Selanjutnya, hasil penelitian menunjukkan bahwa green style and design tidak berpengaruh terhadap kepuasan waisatawan. Hal ini disebabkan oleh tata rancang, aksesibilitas dan arsitektur wisata di hutan mangrove masih dalam tahap pengembangan dan perbaikan sehingga detail fasilitas masih perlu diperbaiki untuk meningkatkan kepuasan wisatawan.

Minat kunjung ulang dalam penelitian ini dipengaruhi oleh variabel green feature dan green style and design. Sesuai dengan alasan sebelumnya bahwa keindahan alam dan konservasi hutang mangrove mampu menarik wsiatawan untuk berkunjung ulang. Selain itu walaupun tata rancang area objek wisata belum optimal, akan tetapi hal ini mampu menarik wisatawan untuk berkunjung ulang. Hal ini disebabkan keunikan desain dan style yang menyatu dengan alam (Archan \& Khan, 2017).

\section{KESIMPULAN}

\section{Simpulan}

Berdasarkan hasil penelitan dapat disimpulkan bahwa:

1. Green feature berpengaruh positif terhadap kepuasan wisatawan hutan mangrove.

2. Green performance berpengaruh positif terhadap kepuasan wisatawan hutan mangrove.

3. Green style and design tidak berprengaurh terhadap kepuasan wisatawan hutan mangrove.

4. Green feature berpengaruh positif terhadap minat kunjung ulang wisatawan hutan mangrove 
5. Green performance tidak berpengaruh terhadap minat kunjung ulang wisatawan hutan mangrove.

6. Green style and design berpengaruh positif terhadap minat kunjung ulang wisatawan hutan mangrove.

7. Kepuasan wisatawan tidak berpengaruh terhadap minat kunjung ulang.

\section{Saran}

1. Pengelola wisata hutan mangrove perlu meningkatkan kualitas pelayana dengan menyediaan pemandu wisata yang komunikatif dan mengerti tentang hutan mangrove.

2. Perlu inovasi ragam fasilitas yang disediakann di hutan mnagrove, misalkan gazebo-gazebo, atau lokasi-lokasi yang mnarik untuk objek foto

\section{REFERENSI}

Mitra, Archan \& Asif Khan. 2017. Green Tourism Management in India- 'A 3D Study of the Seven Sisters States of North- East with Special Reference to Eco- Tourism. International Journal of Innovative Research in Science, Engineering and Technology. Vol. 6, Issue 4, April 2017

Augusty, Ferdinand. 2006. Metode Penelitian Manajemen: Pedoman penelitian untuk skripsi, Tesis dan Disertai Ilmu Manajemen. Semarang: Universitas Diponegoro.

Bitner, M. J. dan Zeithaml, V. A., 2003, Service Marketing (3rd ed.), Tata McGraw Hill, New Delhi.

Cronin, J.Joseph Jr dan Steven Taylor, (1992), Measuring Service Quality: Reexamination and Extension, Journal of Marketing.

David Harianto dan Hartono Subagio, 2013. “ Analisa Pengaruh Kualitas Layanan, Brand Image, dan Atmosphere terhadap Loyalitas Konsumen Dengan kepuasan Konsumen Sebagai Variabel Intervening Konsumen Kedai Deja-vu Surabaya”. Jurnal Manajemen Pemasaran Vol.1, No.1
Dian Permana. 2012. Pengaruh Diferensiasi Produk "Green Tourism Destination" Terhadap Kepuasan Berkunjung di Pulau Sikuai. Skripsi Program Studi Manajemen Pemasaran Pariwisata UPI. Bandung: Tidak diterbitkan

Fandeli, Chafid. (2002). Perencanaan Bayu, Irda dan Rosha, Zeshasina. 2013. Pengaruh Strategi Diferensiasi Terhadap Kepuasan Pelanggan Maskapai Penerbangan PT. Garuda Indonesia Di Kota Padang. Jurnal Manajemen. Volume 1 Nomor 2

Fandeli, Chafid. 2000. Pengusahaan ekowisata. Penerbit Fakultas Kehutanan UGM.Suwantoro Gamal, 1997. Dasardasar Pariwisata. Edisi Pertama. Cetakan Pertama. Penerbit Andi. Yogyakarta

Fornell, C. (1992) A National Customer Satisfaction Barometer: The Swedish Experience. Journal of Marketing, Vol. 56

Hasan, Ali. 2015. Tourism Marketing. Yogyakarta: Center for Academic Publishing Service.

Husein Umar. 2000. "Metodologi Penelitian". Gramedia Pustaka Umum, Jakarta.

Kotler, Philip, 2002, Manajemen Pemasaran, Jilid 1, Edisi Milenium, Jakarta, Prehallindo.

Kotler, Philip, 2008. Manajemen Pemasaran, Edisi Milenium diterjemahkan Benyamin Molan, PT. Prenhallindo, Jakarta.

Kotler, Philip dan Armstrong, Gary. (2011). 10th Edition. "Marketing an Introduction". Indonesia: Perason.

Mowen, J. dan Minor, M (2007). Perilaku Konsumen. Jakarta : Erlangga.

Rangkuti, Freddy (2002). Measuring Customer Satisfaction.Teknik Mengukur dan Strategi Meningkatkan Kepuasan Pelanggan dan Analisis Kasus PLN-JP. PT. Gramedia Pustaka Utama, Jakarta.

Riyanto, Sofyan.,BSEE.,MBA. (2012). Prospek Bisnis Pariwisata Syariah. Jakarta: Republika

Söderlund, Magnus dan Mats Vilgon; (1999:No.1). Customer Satisfaction and 
Links to Customer Profitability : an

Empirical Examination of the

Association Between Attitudes and

Behavior, Working Paper Series in

Business Administration.

Suliyanto. (2006). Metode Riset Bisnis. Yogyakarta: Andi.

Tjiptono Fandy, Ph.D, 2014, Pemasaran Jasa.

Yogyakarta: Andi.

Zeithmal, Parasuraman. 2009. Service Quality : A Conceptual Framework For Understanding implication for Future Research and Managerial Practice : Msi Monograph New York. 